\title{
The Outline of T'ang Poetry Studies in Southeast Asia
}

\author{
Rui Zhou ${ }^{1}$ \\ ${ }^{1}$ Center of Chinese Poetics Studies, Southwest University, Chongqing, China \\ Correspondence: Rui Zhou, Center of Chinese Poetics Studies, Southwest University, Chongqing, China. Tel: \\ 86-139-9622-2299. E-mail: zkidult@hotmail.com
}

Received: June 15, 2014 Accepted: June 26, 2014 Online Published: June 26, 2014

doi:10.5539/ach.v6n2p261 URL: http://dx.doi.org/10.5539/ach.v6n2p261

\begin{abstract}
To get close to Chinese nationalities and push forwards the mutual understanding of Chinese tradition, many overseas institutes and research centers for T'ang poetry studies as the heritage of ancient China had been established recently. In Southeast Asia, the research on T'ang poetry and its embedded traditional culture is not so popular compared with those in North America, Western Europe and East Asia, but it features its own characteristics. This paper tries to reveal the current situation and introduce the achievements in T'ang poetry studies in the main countries in Southeast Asia, including Singapore, Malaysia, Indonesia, Phillipines and Thailand, and finds the peculiarity of the research progress in this area.
\end{abstract}

Keywords: classical Chinese literature, T'ang poetry, translation, overseas China studies, Southeast Asia

\section{Introduction}

As the economic centers of the world, the relationship between China and western world has been increasingly intimate, and China studies becomes a heated academic topic in research field. China has followed a diplomatic policy to communicate its value and heritage to build up a healthy and peaceful international image, making teaching and learning Chinese become more and more popular around the world via ubiquitous Confucius Institutes. Apart from this, in various centers for China Studies, classical Chinese literature is a tradition, or, safe way to get close to Chinese nationalities to push forwards the understanding of traditional Chinese thought.

There is a school of famous scholars who have academic interests in T'ang Poetry studies, covering three main aspects - translation, education and academic research. Japanese scholars have made great achievement with the advantage of easy geographic access to Chinese cultural circle, so does South Korea, while there are many research centers on Sinology, or China studies, have been established in Europe and North America in recent decades, which also have done a lot of research on T'ang Poetry, such as the history, theory and criticism of poetry along with the translation in their linguistic circle. It is worth noting that the present situation about the studies on T'ang poetry in Southeast Asia is drawing attention from the mainstream academic statistics. Southeast Asia has its own different languages and cultures, most of which has founded near or far relationship with China associated with the flow of Chinese immigrants since Ming and Ching Dynasty (A.D.1368-1912). It is believed that over 80 percent overseas Chinese now live in Southeast Asia. Taking the research on the outline of T'ang poetry studies in Southeast Asia is a supplementary pursuit to improve the history and interaction of Chinese and overseas academic fields. Bearing this in mind, the current paper tries to present and summarize the phenomenon and materials of T'ang poetry studies in Southeast Asia and find out some patterns or principles involved. In particular, Vietnam falls into the cultural circle of East Asia, given the western academic tradition, and Laos, Cambodia, Myanmar, Brunei are excluded due to the shortage of research.

\section{Outline of Research in This Area}

\subsection{Singapore}

Singapore might be the community most similar to China in Southeast Asia with a population composed of 75 percent Chinese descendants and diverse ethnic groups. As one of the world's leading commercial hubs, it contributes a lot to the academic research on T'ang poetry studies and its local context. Singapore boasts some of best educational institutes with a high international ranking, such as National University of Singapore (NUS), Nanyang Technological University (NTU) etc where some scholars are working. 
Wong Yoon Wah 王潤華, born in Perak, Malaysia, is a Singaporean citizen. He received his bachelor and master degree in National Taiwan Chengchi University, and then moved to U.S.A. to further his research career. During his doctoral studies at the University of Wisconsin at Madison, Under the instruction of his tutorship, Prof Cezong Zhou 周策縱, a famous Sinologist,he focused his interests on a poet and critic of late T'ang Dynasty, Ssu-k'ung T'u 司空圖. Based on his Ph.D dissertation, Ssu-Kung Tu: The Man and His Theory of Poetry, he published his monograph, Ssu-Kung Tu : a poet-critic of the Tang in 1976 at Chinese University of Hong Kong and compiled his symposium, New Studies on Ssu-Kung Tu 司空圖新論, published by Tungta Books 東大圖書 in 1989 at Taiwan, and some papers had been highly evaluated in academic circle, such as Ssu-Kung Tu's Expressive Theory of Poetry, is considered to apply American Prof. M.H.Abrams' theory to classical Chinese literature study successfully. Besides, he translated Ssu-k'ung T'u's representative critic work, Twenty-four Varieties of Poetic Experience 二十四詩品 into English at National University of Singapore in 1994. Prof. Wong has broadened his academic horizon to Wang Wei 王維, for which the monograph Poetic Study on Wang $W e i$ 王維詩學 has been published by University of Hong Kong in 2009, thus his own composed regulated verse is influenced by the style of Wang Wei's. To commemorate his supervisor, he summarized his tutor's research methodology in Sinological Study of Ethnic Chinese Sinologist, Cezong Zhou 華裔漢學家周策縱的漢學研 究,(Academy Press 學苑, Beijing, 2011). Prof. Wong Yoon Wah was an active scholar during his stay at Singapore where he had once served as President of the Singapore Association of Writers, as well as professor and Head of the Department of Chinese Studies, National University of Singapore, and currently, he is also the Senior Vice President of Southern University College, Malaysia, while holding other guest professor titles in many universities. He might be one of the most famous T'ang Poetry experts in Southeast Asia.

Yeo Song Nian 楊松年 is a Singapore citizen who obtained his Ph.D in University of Hong Kong. He was a professor in National University of Singapore and the first chairman of Singapore Literature Society, and a famous scholar in Fo Guang University in Taiwan. His main achievement of T'ang poetry study has been got on $\mathrm{Tu} \mathrm{Fu}$ 杜甫 which might be displayed on his monograph Research on Tu Fu's 'Joking Remarks on Six Quatrains' 杜甫《戲為六絕句》研究, (Literature, History and Philosophy Press 文史哲,Taipei,1995). In this book, he tried to sum up the academic history of the series of poems on poetic criticism, such as the creative motivation, reviews on former poets, influence on literary criticism via series quatrains in the future, and so on, and his critical remarks on every word in this series quatrains in the main body of the book has demonstrated his ability and intelligence in literary criticism particularly. He has published some important papers in related fields, including Chinese literary criticism and Chinese literature in Southeast Asia. Prof. Yeo has retired now.

Though he had just received secondary education only, yet Mr.Tseng Shih Bong 曾希邦 was enamored of traditional Chinese culture and tried to translate T'ang poetry into English. Born in Singapore, Mr.Tseng was the editor of NanYang Siang Pau 南洋商報,Sin Chew Daily 星洲日報 and so on. He has two Chinese-English books on T'ang poetry (including Sung lyrics and other traditional poetic writing), one is English Translation of Thirty-eight Chinese Ancient Poems 英譯古詩三十八首, and the other is English Translation of Twenty-six T'ang and Sung Lyrics 英譯唐宋詞二十六首, both of them are published by Cosmos Books 天地圖書 in Hong Kong during 2009-2011. Mr.Tseng's free style translation reads smooth, without consideration of rhythms to keep concordance with the Chinese version, but his poetic passion and artistic conception makes up his deficiency, some translated sentences are marvelous. He is strongly recommended by one of his apprentices, Chua Lam 蔡瀾, a well-known filmmaker, writer and businessman, so that he won great reputation in Chinese cultural circle.

There are some energetic scholars in NUS and NTU deserving to be mentioned, such as Dr. Lam Lap 林立 in T'ang folk lyrics, I Lo-fen 衣若芬 in poetry and painting, Crossland Guo Shuyun 郭淑雲 in Tun-huang Literature, etc.

\subsection{Malaysia}

Although the official languages of Malaysia are Malaysian and English, Chinese Malaysians who are playing important roles in Malaysian multi-cultural society predominantly speak mandarin Chinese and dialects prevalent in Southern China, including Cantonese, Hokkien and Hakka. Chinese culture takes up a very important proportion of Malaysian multi-ethnic culture with an example of its prosperity that is the great scale of Chinese schools in Malaysian system of education. The majority of researchers on T'ang poetry studies are active in universities and institutes.

The Association of Translation and Creative Writings in Malaysia is the base of Chinese-Malay translation of ancient Chinese literature, where one of the most outstanding achievements is Malay version of Four Great 
Classical Novels of China. Some China Studies centers had been established to research T'ang poetry in colleges and institutes, such as Malaya, Putra, Rahman, etc.

Born in Kuala Lumper, the president of the association, Goh Then Chye 吳天才, once was the head of Department of Chinese Studies at University of Malaya and a translator of Chinese poetry for UNESCO. Being a translator, Prof. Goh's translation focuses on Chinese literature to Malay language and vice versa. He is regarded as a pioneer translator in turning Chinese poems into Malay language with Modern Chinese Poetry : A Bibliography 1917-1949 中國新詩集總目 and Contemporary Chinese Poetry: A Bibliography 1950-1980 中國 現代詩集編. However, as far as T'ang Poetry is concerned, it seems no evidence to prove even though it is believed that Mr. Goh might have done endeavor in classical poems.

Prof. Lim Chooi Kwa 林水檺 is a outstanding research scholar in T'ang Poetry and classical Chinese literature in Malaysia. Since he ever studied at National Taiwan University, The University of British Columbia (Canada) and the University of Malaya, he has fostered versatile methodology of Chinese literary criticism. He is a respectable faculty in Institute of Chinese Studies at Universiti Tunku Abdul Rahman. Based on his research on T'ang poetry, a huge number of articles have been published, covering numerous important T'ang poets such as Li Po 李白, Han Yü 韓愈, Liu Yü-hsi 劉禹錫, Liu Tsung-yuan 柳宗元, Wei Ying-wu 韋應物, and even Li Hsün 李珣, a minor poet in Five Dynasties with Persian strain. His Ph.D dissertation Liu Yü-hsi (772-842 A.D): The Life and Works of a T'ang Scholar 劉禹錫及其作品研究 is a comprehensive research of case study on an individual which won a good reputation for him. What is more, he is good at summarizing the experience of overseas Chinese literature communication. Transmission of Chinese Literary Heritage: A Case Study of Malaysia 中國文學遺產之傳承: 馬來西亞的個案(Conference Proceedings of International Forum for Literary Heritage, Chongqing, 2007, pp69-79) is a symbol of his research on literary relationship between traditional Chinese and Southeast Asian counterparts. And Universiti Tunku Abdul Rahman also serves as an important research base for Chinese studies, where another scholar concentrating his interest on T'ang poetry is Dr. Lim Chee Men 林志敏.

Born in Kedah, Fan Pik Wah 潘碧華, who graduated from the University o f Malaya with Bachelor and Master of Arts degrees in Chinese Studies, obtained her PhD degree in Peking University, China in Chinese Classical Literature and now is the senior lecturer in Department of Chinese Studies in University of Malaya. Her research area is classical Chinese literature. She has been writing literary research articles for academic journals, ranging from late T'ang to Five Dynasties, for instance, Wen T’ing-yün 溫庭筠, Li Yü 李显, and her Ph.D dissertation is On Feminine Writing of T'ang \& Sung Lyrics 論唐宋詞的女性書寫. She has a special interest on music literature of T'ang Dynasty.

\subsection{Indonesia}

There are about 300 ethnic groups in Indonesia, among which Chinese, wielding influential power to the society, is a minor ethnic with a 3-4\% in total population. During the 32 years of the New Order regime in Indonesia, any room was given to the development of the ethnic Chinese culture. As a result, the ethnic Chinese culture became alienated in Indonesia. Some Chinese-Indonesians tried to break the ice after the collapse of the New Order regime in the new era to fill up with the gap of communication on T'ang poetry and other classical Chinese literature in Indonesia. However, it seems a long way to go before arriving at a new stage for Chinese studies in the official academic institutes. Some top university have the Department of Chinese Studies, such as Universitas Indonesia, Gadjah Mada, Airlangga, and so on.

Wilson Tjandinegara(Chen Tung Long)陳冬龍 is considered as a pioneer of cultural exchange thanks to a substantial role he has played bridging ethnic Chinese and Indonesians. He has several translative works published, one of which is Dinasti Tang : Antologi Sajak Klasik, (Versi Modern), Mandarin-Indonesia 唐詩選 [漢譯印尼語] (Komunitas Sastra Indonesia, 2001), is regarded as the first T'ang poetry translative monograph in Indonesian history. He is the dean of Department of Communication in Perhimpunan Penulis Tionghoa Indonesia 印尼華文寫作者協會 and inspired other Chinese-Indonesians to advance his career in translation of T'ang Poetry.

Later, another younger scholar published a similar Chinese-Indonesian translation book on classical Chinese poems, named Purnama di Bukit Langit: Antologi Puisi Tiongkok Klasik 明月出天山: 中國古代詩歌選 (Gramedia Pustaka Utama, 2007) . He is Fuyuan Zhou 周福源. Actually this translator is an architect and was forced to terminate his Chinese education in his childhood. He selected translating 172 T'ang poems into Indonesian along with additional biographies of six renowned poets, Li Po, Tu Fu, Wang Wei, Po Chu-i 白居易, Li Ho 李賀 and Li Shang-yin 李商隱. It might be the best available version nowadays with natural rhymes 
usually occurring at the similar place to the original poems in his translative ones and illustrations demonstrating the artistic conception as well.

What is more, Mr. Minggus Tedja 戴俊德, the head of Elegance Poetry Society 儒雅詩社 in Java, Indonesia, had translated a great number of T'ang poems for a local Chinese journal 《呼聲》 in Jakarta and drew attention from the local Chinese to read T'ang poetry. He even summed up the prosody and versification of regulated verse to the masses via Introductory Lecture to Chinese Regulated Verse Writing 格律詩寫作入門講義 as an appendix to his self-composed poems collection, Lingering Charm of Refine Elegance 儒雅餘韻 (Komunitas Sastra Indonesia, 2009).

At last, It is worth mentioning that Mr. Zhang Ling 凌彰. He was born in Kalimantan in Indonesia and moved to Mainland China when he was 19. Besides translating T'ang poetry into Indonesian, this old overseas Chinese collected the outline of T'ang poetry studies around the world. He is a venerable folk scholar and continues updating his blog.

\subsection{Philippines}

Although there is an estimated over 1 million Filipinos who have partial Chinese ancestry, and have a prominent role in the country's economy, Chinese Filipinos seldom received Chinese education in the past and had been assimilated into pure Filipinos. T'ang poetry communication is not so popular in Filipino academic circle.

Yingzhou Shi 施穎洲 is the most renowned scholar, devoting himself to the translation. Not only working as the leader in pushing forward the Filipino-Chinese movements and organizations, such as the chairman of Filipino-Chinese Federation of Literary and Art Circles 菲律賓華僑文藝工作者聯合會 and the editor in chief of United Daily (聯合日報 a Chinese newspaper in Philippines), he is the top-class translator on T'ang poetry in Philippines as well. He published his translative monograph on classical Chinese poetry at the age of 87: Tang and Song Poetry: Chinese-English 中英對照讀唐詩宋詞 (Chiuko Press 九歌出版社, 2006), in which five of sixth are T'ang poetry. The most prominent feature of his translation of T'ang poetry is faithfulness and gracefulness. Embracing a large number of others' translation, he picked up the most appropriate words in his translative version, which are loyal to the original in order to keep the aesthetic tasty. Particularly in the phonological structure, Mr. Shi applied the iambic tetrameter to translation of the pentasyllabic Chinese poem and the iambic pentameter to that of heptasyllabic one successfully. His translation is highly recommended by such prominent scholars as Chih-tsing Hsia 夏志清, Cezong Zhou 周策縱, Guangzhong Yu 余光中,etc.

Claro Ben Lim 林健民 is another distinguished translator on T'ang poetry. His translative work Ancient Chinese poems as Translated: In Parallelism Style 中國古詩英譯：整齊美集(Filipino-Chinese Arts Federation 菲華㙯 文聯合會, 1988) insists on the principle of parallelism. The translative version keeps the beauty of aesthetics, which that the number of English alphabet is strictly same to that of original one so that it reads smooth and fluent similar to the Chinese poem. His art of translation skills is worth noting.

Both of Mr. Shi and Mr. Lim are national treasures in Filipino-Chinese art circles, attracting more and more Filipino attention to T'ang poetry.

\subsection{Thailand}

Thailand has a total of more than 65 million people nationwide. Thais is the main ethnic groups, accounting for $75 \%$ of the total population, while 14 percent is Chinese ethnic with the majority are the descendants of Cantonese who immigrated from Chiuchow and Sawtow 潮汕 area since Ching Dynasty.

Chinese teaching and learning had been prohibited by the government due to some political reasons since 1950s, and most of Thai Chinese had changed their Chinese surnames. So nearly all Thai Chinese identify themselves completely as Thai due to the highly successful integration of Chinese communities into Thai society now. Given this assimilation, nearly all ethnic Chinese in Thailand speak Thai exclusively. With the rapid development of economic communication between Thailand and China, Chinese education was allowed to resume in 1990s. Incredibly, Chinese has been one of the most popular foreign languages in Thailand, and has become an optional course in almost every school in Thailand now. As a treasure of Chinese heritage, T'ang poetry studies has drawn academic attention and made some progress here.

Prior to be mentioned in the area of T'ang poetry translation into Thai is a noble royal highness princess, Maha Chakri Sirindhorn มหาจักรีสิรินธร 詩琳通. She is a genius of linguistics, gifted with many western and oriental languages including English, French, German, Latin and Khmer, Pali, Sanskrit and so on, and her special interests in Chinese is worthy noticing. In recent years Princess Sirindhorn has paid many visits to China, both officially and privately, for her studies of the Chinese language and culture. She got her degree in Chulalongkorn, Silpakorn and Srinakharinwirot, some top universities in Thailand. 
There is no doubt that she is the most influential translator introducing classical Chinese poetry into Thailand. She has two anthologies on translation of T'ang and Sung poems, one collecting over 100 poems, a selection with a volume of 34 poems, and T'ang poems almost occupying half, and another named Poetry \& Lyrics as Jade Carving หยกใสร่ายคำ 玩玉詩詞 (Department of Chinese, Thammasatt University,ภาควิชาภาษาจีน มหาวิทยาลัยธรรมศาสตร์, 1998). The latter has comprehensive influence because it is re-published several times ever since its first edition. After introducing the definitions and types of Chinese poetry and lyrics, and the reason why she translated, she translated poems word by word in Chinese phonetic alphabet, Chinese character and Thai correspondingly with illustrations. The most renowned poets and their works in T'ang Dynasty had been selected, such as Meng Hao-jan 孟浩然, Wang Chi-huan 王之渙, Wang Wei, Li Po, Ts'ui Hao 崔影, Tu Fu, Po Chu-i, Liu Tsung-yuan, Tu Mu 杜牧 and Li Shang-yin, majority of the works are quatrains 絕句. For example, the first poem is Spring Dawn รุ่งอรุณฤดูใบไม้ผลิ 春曉, what is more, she expanded this poem to three other quatrains to express her impression and match them as song lyrics with Collecting Peach Blossom จีนเด็ดดอกไม้ เถา 採桃花, a song of classical Thai music. This book is appointed as the reference book for college students who major in Chinese studies nowadays.

Mr. Yong Yingkhawet ยง อิงคเวทย์ 黃榮光 has enjoyed a high reputation on translation of Chinese poems to Thai. He acted as a officer in Ministry of Education as well as a faculty in many famous universities. His major translative interest is Chinese poems during the beginning to Six Dynasties, Evolution of Chinese Poetry วิวัฒนาการกวีนิพนธ์จีน 中國韻文纂譯, Sathirakoses Nagapradjpa Foundation,มูลนิธิเสฐียรโกเศศ-นาคะประทีป 1989). His masterpiece on T'ang poetry studies is Poetry: Songs of life in China ซือ เพลงแห่งชีวิตของจีน 詩: 中 國生命之歌(Bangkok Art \& Culture Press ศิลปวัฒนธรรม, 1986), with Mr. Thaworn Sikkhakoson ถาวร สิกขโกศล 林運熙 who pursued his master degree at Srinakharinwirot University and takes strong enthusiasm to Chinese culture. In the co-author monograph, it introduces the genres, versification and brief history of classical Chinese poetry dating back from Spring-Autumn Period to T'ang Dynasty. In respect of T'ang poems, the collected 39 poems cover 9, 4 and 3 of $\mathrm{Li} \mathrm{Po}, \mathrm{Tu} \mathrm{Fu}$ and Po Chu-i's respectively. To demonstrate its content and aesthetics, commentary, remark and illustration are joined with the original poems which focus on various themes of war, boudoir, love, farewell, landscape, etc.

There are other scholars who devote themselves on T'ang Poetry studies in Thailand. Tang Chang จ่าง แซ่ตั้ง 陳 長's translative selection, Chinese Poetry บทกวีจีน 中國詩 (Charoenkit Printingโรงพิมพ์เจริญกิจ,1971) is a early version of translation of Chinese poems attached with notes and remarks, in which T'ang poems take up 43 of total 56 from Han to Ching Dynasty with over one quarter by Li Po. Wattana Pattanapong วัฒนา พัฒนพงศ์ translated 12 T'ang poems in interlanguage of English with reference to T.C. Lai 賴恬昌(HongKongese), $A$ Chinese book of friendship (Swindon Book Company,1973), into Thai in his own monograph Friends: Its Significance in Chinese Literature เพื่อน : ความหมายในวรรณกรรมจีน 中國文學中的“友誼” (Dokya Publishing House สำนักพิมพ์ ดอกหญ้า,1987), which themes friendship by analyzing Li Po, Wang Wei and Tu Fu's works in Thai poetic style. Suphat Chaiwatthanaphan สุภัทร ชัยวัฒนพันธุ์ is a lecturer in Huachiew Chalermprakiet University which was funded by Overseas Chinese in Thailand. His History of Chinese Literature ประวัติวรรณคดีจีน 中國文學史(Sukkhapabjai สุขภาพใจ, 2006) mentions 47 T'ang poems which were distributed in Early, High, Mid and Late T'ang by 3, 29, 8, 7, had been translated with a strong Thai style of regulated verse. Oui Boonyapat อุ้ย บุญภัทร 莊明偉 might be contributive to one of the best versions of Chinese-Thai translative T'ang poetry. His100 T'ang Poems ร้อยบทกวีถาง 唐詩泰譯一百首(Shine Publishing House, 2006) has an incredible coverage and amount of T'ang poets, where many less minor important poets and their works had been translated, for instance, 4 from Ts'en Ts'an 岑參, 3 from Liu Ch'ang-ching 劉長卿, 5 from Lu Tung 盧全, 3 from Tu Hsün-ho 杜荀鶴. Chodchuang Nadon โชติชว่ว นาดอน is prolific on Chinese poetry, include Sophisticated Poems คมคำ คมกวี 中國詩菁華(Samit สมิต,1987), View on Meditation: Way to Make Life Happy in Crisis ฌานทรรศน์ : วิธีทำชีวิตให้เป็นสุขในยุควิกฤต 禪觀: 危機中讓生活快樂的方法(Tao Prayook เต๋าประยุกต์, 1997). Furthermore, some works are worth our attention, such as Sompran Promta สมภาร พรมทา, The Autumn Wind Poems of Li Po ลมถดูใบไม้ร่วง บทกวีของหลี่ไป๋( Jatujak จตุจักร,1985), Taweep Woradilok ทวีป วรดิลก, Chapter of Li Po \& Tu Fu in Nine Valuable Poets in the World เก้ารัตนกวีของโลก (Matichon มติชน,1996), and so on.

Chinese teaching and learning has a strong appealing in Thailand where many universities and high schools, like Chulalongkorn, Srinakharinwirot, Burapha, Prince of Songkla, Khon Kaen, Chiang Mai University, etc, had established centers for Chinese Studies or Confucian Institutes to explore T'ang poetry researching and teaching. For example, free digital resource of 190 episodes of a series named I Love T'ang Poetry is available online in Mae Fah Luang University. What's more, the mass media also assumes responsibility for the promotion of Chinese poetry. The Universal Daily News 世界日報, the largest Chinese media in Thailand and charged by 
Taipei's United Daily News 聯合報, is issuing T'ang poems occasionally. Though it illustrates the poems with pictures and in traditional Chinese characters and phonetic symbols 注音符號. Based on the heated T'ang poetry studies, Dr. Kwanjai Kitchalarat 趙美玲, a scholar in Chiang Mai Rajabhat University, dedicated her doctorate dissertation to Classical Chinese Poetry in Thailand, the Spread and Impact of Contemporary 中國古典詩歌在 泰國當代的傳播與影響 (Shanghai University,2010), a good sample to know the overview of this academic field.

\section{Conclusion}

Having a quick review on the outline of T'ang poetry studies in Southeast Asia, we can draw some conclusions safely that with the rapid advancement of Chinese economy, more and more overseas scholars begin to pay attention to the tradition of China. In Southeast Asia, the institute for research on Chinese classical literature and traditional culture is not so popular compared with those in North America, Western Europe and East Asia, but it features its own characteristics. First of all, because of geopolitical adjacency, most who have interests on T'ang poetry either have a close relation to China, or are overseas Chinese, with few of them locals. Secondly, the main content of T'ang poetry studies in this area is translation from Chinese into English or native tongues so that the achievement might be accepted by the native academic circle and applied to education, while the field of aesthetic characteristics and various themes are seldom mentioned. What's more, the poets with their works are concentrated on the most famous ones, such as Li Po whose poems might take up half of the whole T'ang poems selected in some certain anthologies due to his unregulated style and optimistic personality. Finally, there is no undisputable and universal methodology widely accepted by the academic circle of Southeast Asia. Although remarkable research progress has been made, the studies on T'ang poetry still has a long way to go.

\section{Acknowledgments}

This paper is sponsored by "Classical Tang Poetry in Global Contexts", the Project of Key Base of Humanities and Social Science in Chongqing, NO.12SKB009 and "Terminology Translation of Chinese Poetics", the Fundamental Research Funds for the Central Universities, NO. SWU1309412.

\section{References}

Boonyapat, O. (2006). 100 T'ang Poems. Bangkok: Shine Publishing House.

Chaiwatthanaphan, S. (2006). History of Chinese Literature. Bangkok: Sukkhapabjai.

Fan, P. W. (2005). On Feminine Writing of T'ang \& Sung Lyrics. Doctoral dissertation. Peking University, Beijing, China.

Kitchalarat, K. (2010). Classical Chinese Poetry in Thailand, the Spread and Impact of Contemporary. Doctoral dissertation. Shanghai University, Shanghai, China.

Lim, C. B. (1988). Ancient Chinese poems as Translated: In Parallelism Style. Manila: Filipino-Chinese Arts Federation.

Lim, C. K. (1992). Liu Yü-hsi (772-842 A.D): The Life and Works of a T'ang Scholar. Doctoral dissertation. University of Malaya, Kuala Lumper, Malaysia.

Maha, C. S. (1998). Poetry \& Lyrics as Jade Carving. Bangkok: Department of Chinese, Thammasatt University.

Pattanapong, W. (1987). Friends: Its Significance in Chinese Literature. Bangkok: Dokya Publishing House.

Shi, Y. (2006). Tang and Song Poetry: Chinese-English. Taipei: Chiuko Press.

Tjandinegara, W. (2001). Dinasti Tang: Antologi Sajak Klasik Mandarin-Indonesia. Bahasa: Komunitas Sastra Indonesia.

Tseng, S, B. (2009). English Translation of Thirty-eight Chinese Ancient Poems. Hong Kong: Cosmos Books.

Tseng, S. B. (2011). English Translation of Twenty-six T'ang and Sung Lyrics. Hong Kong: Cosmos Books.

Wong, Y. W. (1989). New Studies on Ssu-Kung Tu. Taipei: Tungta Books.

Wong, Y. W. (2009). Poetic Study on Wang Wei. HongKong: University of Hong Kong.

Yeo, S. N.(1995). Tu Fu's 'Joking Remarks on Six Quatrains'. Taipei: Literature, History and Philosophy Press.

Yong, Y. (1989). Evolution of Chinese Poetry. Bangkok: Sathirakoses Nagapradjpa Foundation.

Yong, Y., \& Sikkhakoson, T. (1986). Poetry: Songs of life in China. Bangkok: Art \& Culture Press.

Zhou, F. (2007). Bukit Langit: Antologi Puisi Tiongkok Klasik. Jakarta: Gramedia Pustaka Utama. 


\section{Copyrights}

Copyright for this article is retained by the author(s), with first publication rights granted to the journal.

This is an open-access article distributed under the terms and conditions of the Creative Commons Attribution license (http://creativecommons.org/licenses/by/3.0/). 